\title{
Thermal Aging of Mineral Oil-Paper Composite Insulation for High Voltage Transformer
}

\author{
Suwarno and Rizky Auglius Pasaribu \\ School of Electrical Engineering and Informatics \\ Institut Teknologi Bandung, Bandung, Indonesia
}

\begin{abstract}
High voltage transformer is one of the most important equipments in an electric power system. High voltage insulation plays important role in determining transformer performance and greatly determines the lifetime. In general, paper and oil composite is used as main insulations in a high voltage transformer. Due to thermal aging, the insulation performances of the insulation may be degraded. The degradation mechanisms are important to be clarified. This paper reports the experimental results on the effects of thermal aging on the properties of paper-oil composite insulation. The samples used were thermally upgraded kraft paper and mineral oil. They are widely used in high voltage transformers. Samples were conditioned to the same initial conditions through the heating at a temperature of $100^{\circ} \mathrm{C}$ for 24 hours. Mineral oil samples with volume of $800 \mathrm{ml}$ and 6 gram insulating kraft paper were put in hermetical bottles. The paper-oil ratio reflects the typical ratio of oil and kraft paper inside a real transformer. The bottles containing oil and paper samples were subjected to thermal aging at $120^{\circ} \mathrm{C}$ and $150^{\circ} \mathrm{C}$ in a controllable oven for a period up to 4 weeks. Dielectric properties of the oil such as breakdown voltage, resistivity, water content were measured after and before aging. Dissolved gas analysis (DGA) was used to identify the gasses released in the paper-oil composite insulation as the results of thermal aging process. The morphological aging of the kraft paper was investigated using SEM (scanning electron microscopy) while chemical element change was investigated using EDS (energy dispersive spectroscopy) with accelerated voltage of $0.3-30 \mathrm{kV}$. The results showed that the dielectric properties will decrease with the increasing duration and temperature of aging. From these experiments obtained $\mathrm{CO}$ gases, produced from thermal degradation of paper cellulose chain. $\mathrm{H}_{2}$ and $\mathrm{C}_{2} \mathrm{H}_{2}$ gases are not generated in this experiment. The result was consistent since $\mathrm{H}_{2}$ usually generated under partial discharges while $\mathrm{C}_{2} \mathrm{H}_{2}$ released under very high temperature such as partial combustion, electric arc which were not available in the experiment. Some hydrocarbon gas such as $\mathrm{CH}_{4}$, $\mathrm{C}_{2} \mathrm{H}_{4}$ and $\mathrm{C}_{2} \mathrm{H}_{6}$ were detected. $\mathrm{CO}$ gas was obtained as the result thermal aging of paper insulation through oxidation process. The EDS analysis showed that during aging the $\mathrm{C}$ element increased while $\mathrm{O}$ element decreased. EDS data of krafft paper aged at $120^{\circ} \mathrm{C}$ for a duration of 4 weeks (672 hours) taken using JEOL 6510 at accelerated voltage of $10 \mathrm{kV}$ with energy range of $0-20 \mathrm{kV}$ showed that the aged paper consists of 3 elements, $\mathrm{C}, \mathrm{O}$ and $\mathrm{K}$ elements with mass percentage of $75.23 \%$ of $\mathrm{C}$ at energy of $0.277 \mathrm{kV}, \quad \mathrm{O}$ of $21.69 \%$ observed at energy of $0.525 \mathrm{kV}$ and new element of $\mathrm{K}$ with mass percentage of 3.08 observed at energy of $3.312 \mathrm{kV}$. It is clearly observed that $\mathrm{C}$ increased from $58.83 \%$ to $75.23 \%$. This is due to the migration from the ester into the paper on the other hand oxygen reduced from 41.17 $\%$ to $21.69 \%$ because the oxygen from the paper reacted with oil in an oxidation and release $\mathrm{CO}$ gas as confirmed by DGA (dissolved gas analysis). Similar behavior was observed for aging at $150^{\circ} \mathrm{C}$.
\end{abstract}

Keywords: Mineral oil, thermal aging, kraft paper, dielectric properties, dissolved gas analysis, SEM, EDX

\section{Introduction}

It is common that paper and mineral oil are being used as main insulation in a high voltage transformer. Paper insulation in the transformer is generally recognized as the determining

Received: August $19^{\text {th }}, 2016$. Accepted: December $23^{\text {rd }}, 2016$

DOI: 10.15676/ijeei.2016.8.4.9 
factor of the transformer lifetime[1-5]. Cellulose is an organic compound with the formula $\mathrm{n}, \mathrm{a}$ polysaccharide consisting of a linear chain of several hundred to many thousands of $\beta$ linked D-glucose units. The chemical formula of cellulose that compose a paper is $\left(\mathrm{C}_{6} \mathrm{H}_{10} \mathrm{O}_{5}\right)_{\mathrm{n}}$ [6] Typically it has density of $1.5 \mathrm{~g} / \mathrm{cm}^{3}$. The chemical structure is shown in figure 1 .

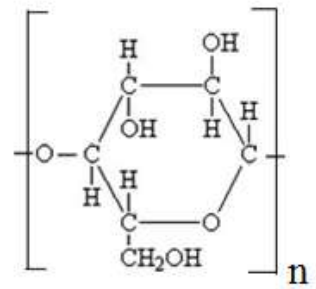

Figure 1. Chemical structure of cellulose

Mineral oil is a complex substances of hydrocarbon. Its chemical formula consists of alkenes (parraffine), cyclic alkenes (napthene), and aromatics. The chemical structure is shown in figure 2 .

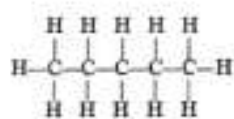

Paraffin<smiles>C1CCCCC1</smiles>

Naphthenes<smiles>c1ccccc1</smiles>

Aromatic

Figure 2. Chemical structure of mineral transformer oil

Mineral oil is the oil insulation used in transformers since long time. During the last century, power transformers have generally been filled with mineral oil, which has good compatibility with the cellulosic insulating paper; good physical and electrical properties, not only as a cooling fluid but also as an electrical insulator; and suitable properties such as good electrical arc quenching and mainly availability, low cost, and long history. Failure of oil insulation may cause the transformer failure leading to the interruption of power delivery. Thermal ageing can change the dielectric properties of insulation oil[7-10]. In this paper, the experimental results on the thermal aging of kraft paper-mineral oil composite insulation is presented. The change of dielectric properties of mineral oil due to the thermal aging is discussed. The generated gases during the thermal aging are analysed using DGA (dissolved gas analysis) method[11-13]. The morphological aging of the kraft paper was investigated using SEM (scanning electron microscopy) while chemical element change was investigated using EDS (energy dispersive spectroscopy)[14-16].

\section{Experimental setup}

\section{A. Sample}

The sample used in the experiment were thermally upgraded kraft insulating paper and mineral oil. Insulating paper is inserted into the bottle with insulating oil. 
Mineral oil samples with volume of $800 \mathrm{ml}$ and 6 gram insulating kraft paper were put in hermetical bottles. The paper-oil ratio reflects the typical ratio of oil and kraft paper inside a real transformer. The bottles containing oil and paper samples were subjected to thermal aging at $120^{\circ} \mathrm{C}$ and $150^{\circ} \mathrm{C}$ in a controllable oven for a period up to 4 weeks. The selected temperature is in accordance with Mc Shane [17], while the temperature of $120^{\circ} \mathrm{C}$ is a maximum hotspot temperature according to the IEEE[18]. Prior to aging, the sample is heated at a temperature of $100^{\circ} \mathrm{C}$ for 24 hours in order to obtain the same initial conditions. The sample name and treatments are shown in table 1.

Table 1. Sample and treatment

\begin{tabular}{|c|c|}
\hline Sample & Aging \\
\hline M. T0 & Initial State \\
\hline M. T1. 120 & $120^{\circ} \mathrm{C}$ for 336 hours \\
\hline M. T1. 150 & $150^{\circ} \mathrm{C}$ for 336 hours \\
\hline M. T2. 120 & $120^{\circ} \mathrm{C}$ for 672 hours \\
\hline M. T2. 150 & $150^{\circ} \mathrm{C}$ for 672 hours \\
\hline
\end{tabular}

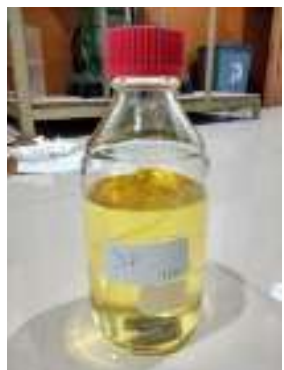

Figure 3. Photographs of typical sample before thermal aging

\section{B. Measurement of Dielectric Properties}

\section{B.1. Breakdown voltage}

Breakdown voltage testing is done by using LD60 model of Liquid Dielectric Test made in Phenix Technologies. Standard used in breakdown voltage testing is IEC 60156 [19]. According to the used standard, breakdown voltage has been defined as the magnitude of the voltage when electrical breakdown occurs between the two ball electrodes within $2.5 \mathrm{~mm}$ at a rate of voltage rise of $2000 \mathrm{~V} / \mathrm{s}$. The used testing cells are both of the ball electrodes. The size of the testing cell is $10 \times 8 \times 8 \mathrm{~cm}$ and made from acrylic material. Liquid insulation samples which their breakdown voltage will be tested, is inserted into the testing cell. LD60 model of Liquid Dielectric Test uses the input of $220 \mathrm{~V}, 50 \mathrm{~Hz}$.

\section{B.2. Resistivity}

The testing is intended to determine the resistivity of the type of tested samples. The equipment used in this test is a High Resistance Meter. The test is carried out by using tube electrode which is part of Tettex Instruments and also used in Tan $\delta$ testing. Type resistivity testing is done with reference to the standard of IEC 60247 named "Insulating liquids Measurement of dielectric constant, dielectric dissipation factor ( $\tan \delta$ ) and dc resistivity". [20]

\section{Dissolved Gas Analysis}

Analysis of the type and concentration of gas contained in the oil sample is done with Gas Chromatograph HP 6890. The procedure to extract the gas from the oil sample refers to the IEEE and ASTM standards[21,22]. Oil samples were placed in a vial. Vials contain the sample is then placed in the sample container. An automated sample traction device, Automatic Liquid Sampler HP 7649, works to take the vial containing the sample one by one from the container 
to be analyzed. Vial is shaken by an automatic shaker to extract the gas trapped in the oil. Gas accumulated in the top of the vial is then collected with a needle that also works automatically.

\section{SEM and EDX analysis}

In order to understand the effects of thermal aging on the properties of kraft paper in natural ester several measurements are conducted. They are visual observation, scanning electron microscopy (SEM) and EDS measurement. Morphology of paper was observed using SEM JEOL JSM 6610 series with accelerated voltage of $0.3-30 \mathrm{kV}$ as shown in figure 4 . The equipment has a built in EDS which enables to identify the chemical elements in the paper.

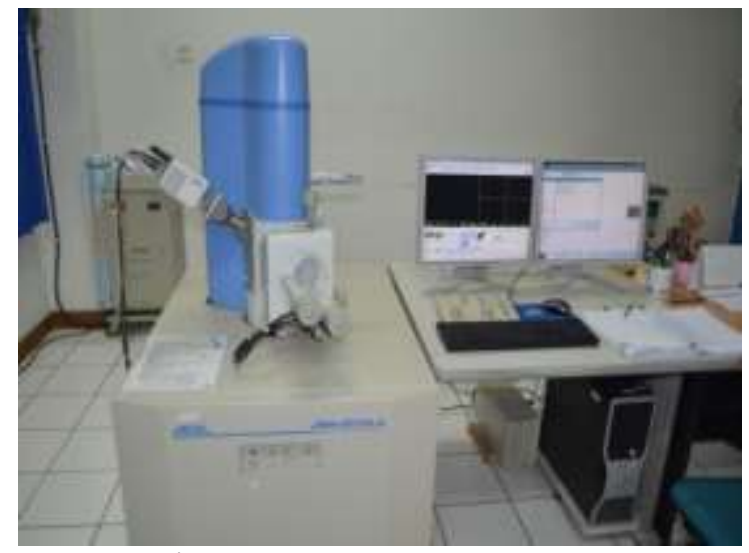

Figure 4. SEM JEOL JSM 6610

\section{Experimental Result and Analysis}

A. Visual appearance

Figure shows visual appearances of oil before aging (a), after aging of 336 hours at $120^{\circ} \mathrm{C}$ (b) after aging of 672 hours at $120^{\circ} \mathrm{C}$ (c) after aging of 336 hours at $150^{\circ} \mathrm{C}$ (d) and after aging of 672 hours at $150^{\circ} \mathrm{C}$.

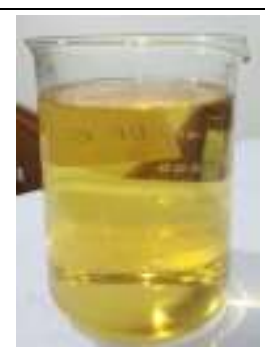

(a)

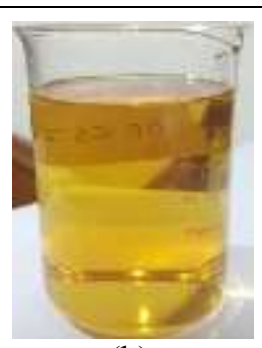

(b)

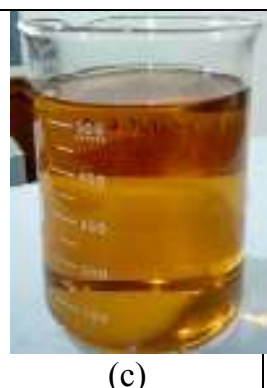

(c)
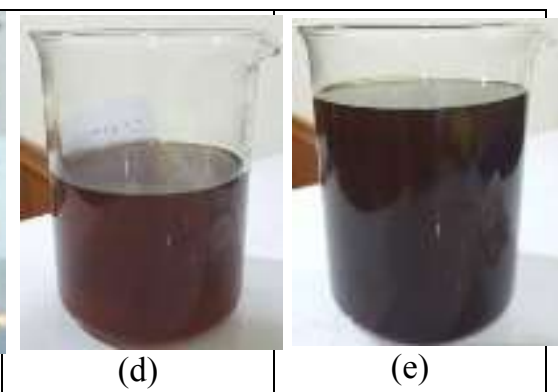

(e)

Figure 5. Pictures of oil samples before and after thermal aging at different temperature and aging time

Figure 5 shows that the color of the oil become darker with aging time and the aging temperature. By using the color scale standard, the color scale of the oil before and after aging are shown in table 2. 
Table 2. Color scale of oil samples before and after aging

\begin{tabular}{|c|c|c|}
\hline Sample & Picture \# & Color scale \\
\hline M. T0 & A & 2.0 \\
\hline M. T1. 120 & b & 2.3 \\
\hline M. T2. 120 & c & 2.8 \\
\hline M. T1. 150 & d & 3.5 \\
\hline M. T2. 150 & e & 4.3 \\
\hline
\end{tabular}

\section{B. Breakdown Voltage}

Breakdown voltage illustrates the dialectric strenght of insulation in a very high electrical voltage. The higher value of breakdown voltage could bring the better dielectric strenght of insulation material.

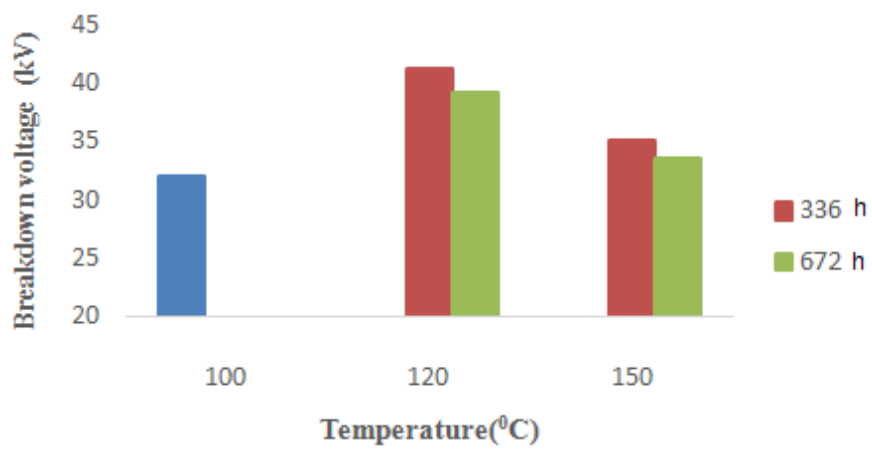

Figure 6. Dependence of Breakdown Voltage on temperature for aging time of 336 and 672 hours

Figure 6 shown breakdown voltage of mineral oil sample before and after aging at $120^{\circ} \mathrm{C}$ and $150^{\circ} \mathrm{C}$ for duration of 336 and 672 hours. The blue bar indicates the breakdown voltage of initial sample after heated at $100 \mathrm{oC}$ for 24 hours. The figure clearly shows that breakdown voltage increases after heating the samples. The phenomena was due to the reduction of water content which was from $64 \mathrm{ppm}$ to $43 \mathrm{ppm}$ after 336 hours. As the time elapsed the breakdown voltage reduced again. This was due to the degradation of the oil as well as paper as indicated by the darker color of the aged oils.

\section{Resistivity}

The test results are given in the following graph.

Figure 7 shows the resistivity of mineral oil as a function of aging temperature. Graph presents the decrease in resistivity value of oil with the increasing aging temperature. Because if the larger temperature given, then greater the energy received by the oil. The condition causes more solid contaminants arise in the form of carbon that is conductive. Thus increasing the conductivity of the insulation on oil continuously will lower the value of resistivity. Such conditions can be seen in the graph, the sample M.T2.150. Samples that are heated $150^{\circ} \mathrm{C}$ and duration of 4 weeks, a lot of the formation of contaminant particles that can increase the conductivity of the insulation of the oil samples. And over time will lower the resistivity of the type of oil. This condition proves that the greater the temperature and duration of aging by, can lower the resistivity value of oil type. 


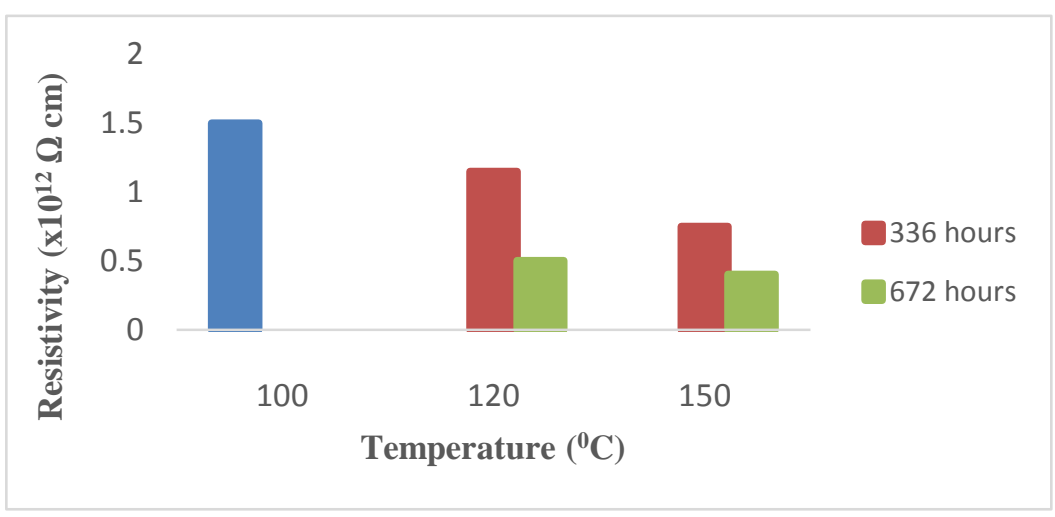

Figure 7. Dependence of Resistivity on temperature for aging time of 336 and 672 hours

\section{Dissolved Gas Analysis}

Table 2 shows the concentration of gases in the ester oil samplesThey are several gases obtained, those are $\mathrm{H}_{2}$ (Hydrogen), $\mathrm{CH}_{4}$ (Methane), $\mathrm{C}_{2} \mathrm{H}_{2}$ (Acetylene), $\mathrm{C}_{2} \mathrm{H}_{4}$ (ethylene), $\mathrm{C}_{2} \mathrm{H}_{6}$ (ethane), and $\mathrm{CO}$ (Carbon Monoxide). In this paper, we collect the concentration all of the gases and choose the most significant gases to interpret the condition of ester oil after ageing process.

From the table 3 it is clear that $\mathrm{CO}$ appeared in all of the samples. At high-temperature cellulose molecules are decomposed and evolve carbon oxides $\left(\mathrm{CO}_{2}\right.$ and $\left.\mathrm{CO}\right)$. High level of dissolved carbon oxides in oil indicates the thermal degradation of cellulose insulation in the system. Hence, it is possible to assess the level of solid insulation degradation using amount of $\mathrm{CO} 2$ and $\mathrm{CO}$ concentration in oil.

In this experiment, the amount gas concentration $\mathrm{H}_{2}$ and $\mathrm{C}_{2} \mathrm{H}_{2}$ were little detected due to different experimental conditions. When high energy of electric defects such as partial discharge or arcs is concentrated on insulating oil, $\mathrm{H}_{2}$ and $\mathrm{C}_{2} \mathrm{H}_{2}$ which the molecular weights are relatively small are generated in large amount because the degree of degradation of insulating oil is high.

The reason why $\mathrm{C} 2 \mathrm{H} 6$ gas were generated in this experimental results considered to be the molecular bonding structures of natural ester fluid. Natural ester fluid is composed of unsaturated fatty acid structures which are compositely composed of double bonds and single bonds of carbon. When these structures are heated, the single bonds $(\mathrm{C}-\mathrm{C})$ that have weak binding force are degraded first to generate hydrocarbon. The hydrocarbon and water weaken the double bonds $(\mathrm{C}=\mathrm{C})$, so that the double bonds are decomposed to single bonds.

Table 3. Gases obtained from DGA

\begin{tabular}{|c|c|c|c|c|c|c|}
\hline \multirow{2}{*}{ Samples } & \multicolumn{6}{|c|}{ Gas Concentration (ppm) } \\
\cline { 2 - 7 } & $\mathrm{H}_{2}$ & $\mathrm{CH}_{4}$ & $\mathrm{C}_{2} \mathrm{H}_{2}$ & $\mathrm{C}_{2} \mathrm{H}_{4}$ & $\mathrm{C}_{2} \mathrm{H}_{6}$ & $\mathrm{CO}$ \\
\hline M. T0 & 0 & 0 & 0 & 0 & 0 & 0 \\
\hline $\begin{array}{c}\text { M. T1. } \\
120\end{array}$ & 0 & 68,52 & 0 & 11,16 & 73,43 & 92,35 \\
\hline $\begin{array}{c}\text { M. T1. } \\
150\end{array}$ & 0 & 21,74 & 0 & 29,17 & 45,40 & 94,10 \\
\hline $\begin{array}{c}\text { M. T2. } \\
120\end{array}$ & 0 & 41,22 & 0 & 11,83 & 39,95 & 110,30 \\
\hline $\begin{array}{c}\text { M. T2. } \\
150\end{array}$ & 0 & 267,39 & 0 & 33,45 & 293,14 & 438,15 \\
\hline
\end{tabular}




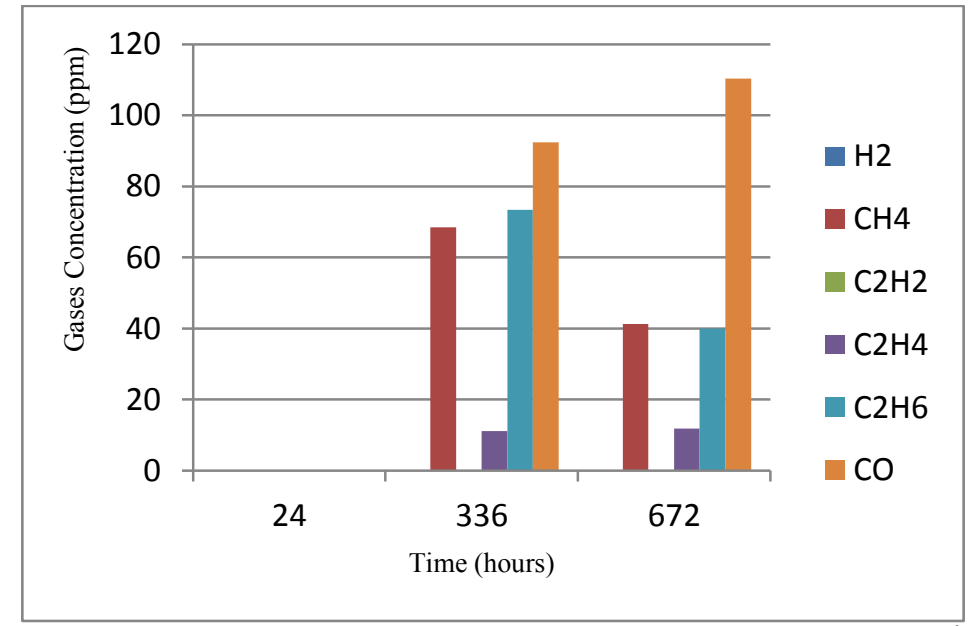

Figure 8. Dependence of Gases Concentration on aging time at $120^{\circ} \mathrm{C}$

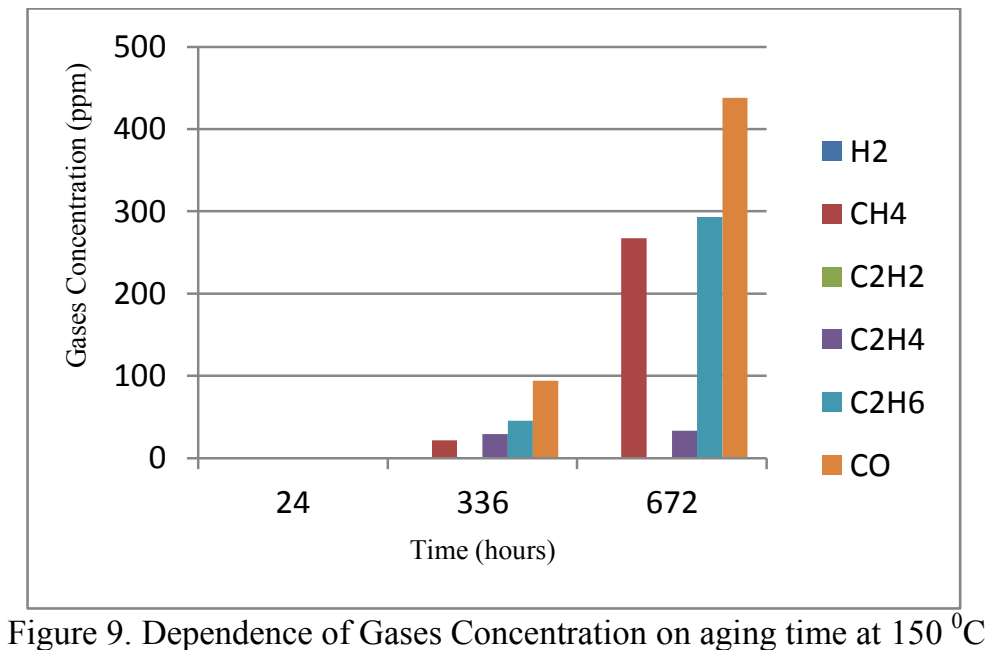

From the graph above, we can see an increase in the concentration of $\mathrm{CO}$. This indicates the occurrence of thermal degradation of the paper cellulose chains [9]. The addition temperature and duration of aging will increase the concentration of $\mathrm{CO}$. Effect of thermal aging can produce $\mathrm{CH}_{4}, \mathrm{C}_{2} \mathrm{H}_{4}$ and $\mathrm{C}_{2} \mathrm{H}_{6}$. The trend of gases concentration increases with increasing temperature aging. Because the gases formed by thermal degradation of paper cellulose chains[23,24].

\section{SEM and EDX Analysis}

SEM and EDS results of a new paper

Figure 10 (a) shows the SEM picture of a new krafft paper taken using accelerated voltage of $20 \mathrm{kV}$ and magnification of $200 \mathrm{x}$. It is seen that there are reasonable pore in the paper. Figure 10 (b) shows the EDS spectrum taken using JEOL 6510 at accelerated voltage of $10 \mathrm{kV}$ with energy range of $0-10 \mathrm{keV}$. From the spectrum it is seen that the new paper is mainly consists of $\mathrm{C}$ and $\mathrm{O}$ elements with mass percentage of $58.83 \%$ of $\mathrm{C}$ at energy of $0.277 \mathrm{keV}$ and $\mathrm{O}$ of $41.17 \%$ observed at energy of $0.525 \mathrm{keV}$. The results are consistent with the facts that Paper is composed of Cellulose which is an organic compound with the formula $n$, a polysaccharide consisting of a linear chain of several hundred to many thousands of $\beta$ linked 
D-glucose units. The chemical formula of cellulose is $\left(\mathrm{C}_{6} \mathrm{H}_{10} \mathrm{O}_{5}\right)$. Hydrogen was not detected because The $\mathrm{H} 1 \mathrm{~s}$ electrons are valence electrons and as such participate in chemical bonding. Any signal from hydrogen would overlap with signals from excitation of valence electrons from other surface atoms. It is generally not possible to distinguish between $\mathrm{H} 1 \mathrm{~s}$ valence electrons and valence electrons of other elements. Therefore, $\mathrm{H} 1 \mathrm{~s}$ valence electrons are not useful in elemental identification using EDS method[25].

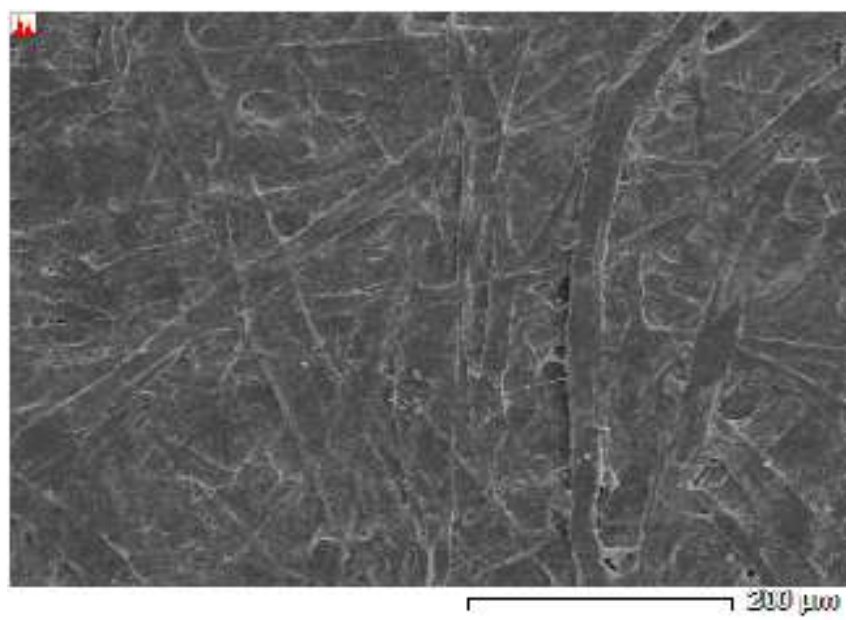

(a)

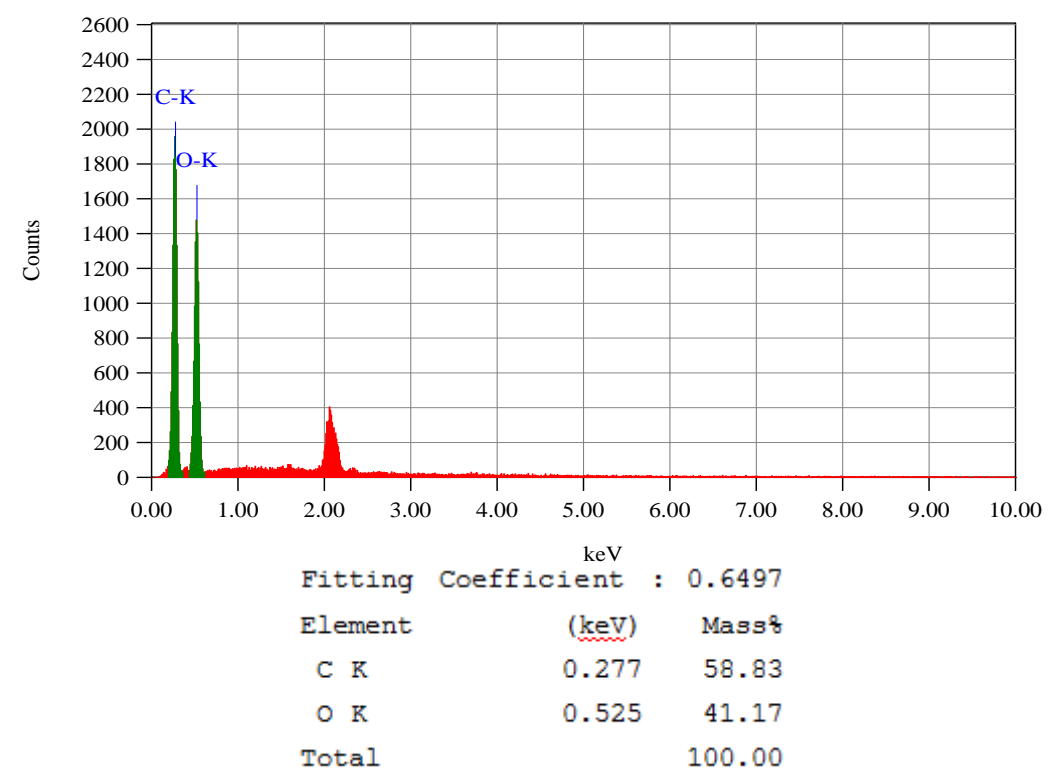

(b)

Figure 10. (a) SEM and (b) EDS spectra for new paper

SEM and EDS results of paper aged at 120 deg for 336 hours in mineral oil

Figure 11 (a) shows the SEM picture of a krafft paper aged at $120^{\circ} \mathrm{C}$ for a duration of 2 weeks (336 hours) taken using accelerated voltage of $10 \mathrm{kV}$ and magnification of $200 \mathrm{x}$. From the figure it is seen that there are reasonable pore in the paper. Figure 11 (b) shows the EDS spectrum taken using JEOL 6510 at accelerated voltage of $10 \mathrm{kV}$ with energy range of 0-10 $\mathrm{keV}$. From the spectrum it is seen that the aged paper consists of 2 elements, $\mathrm{C}$ and $\mathrm{O}$ which 
are similar to those of new paper. However, they have different mass percentages. They are $72.3 \%$ of $\mathrm{C}$ at energy of $0.277 \mathrm{keV}$ and $\mathrm{O}$ of $27.7 \%$ observed at energy of $0.525 \mathrm{keV}$. It is clearly observed that $\mathrm{C}$ increased from $58.83 \%$ to $72.3 \%$. On the other hand oxygen reduced from $41.17 \%$ to $27.7 \%$. This is due to the migration from the oil into the paper and the reduction of oxygen in the paper because of reaction with oil in an thermal agitated oxidation and release CO gas as confirmed by DGA (dissolved gas analysis). As shown in the table 2, 92,35 ppm CO gas was released.

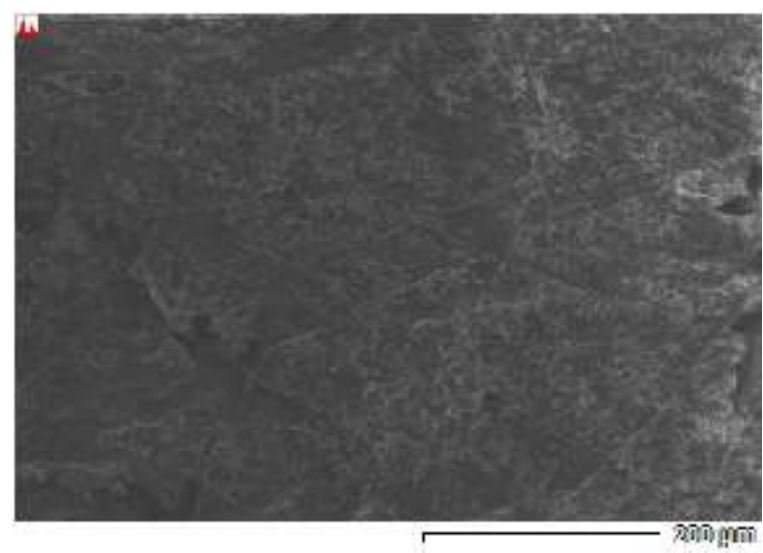

(a)

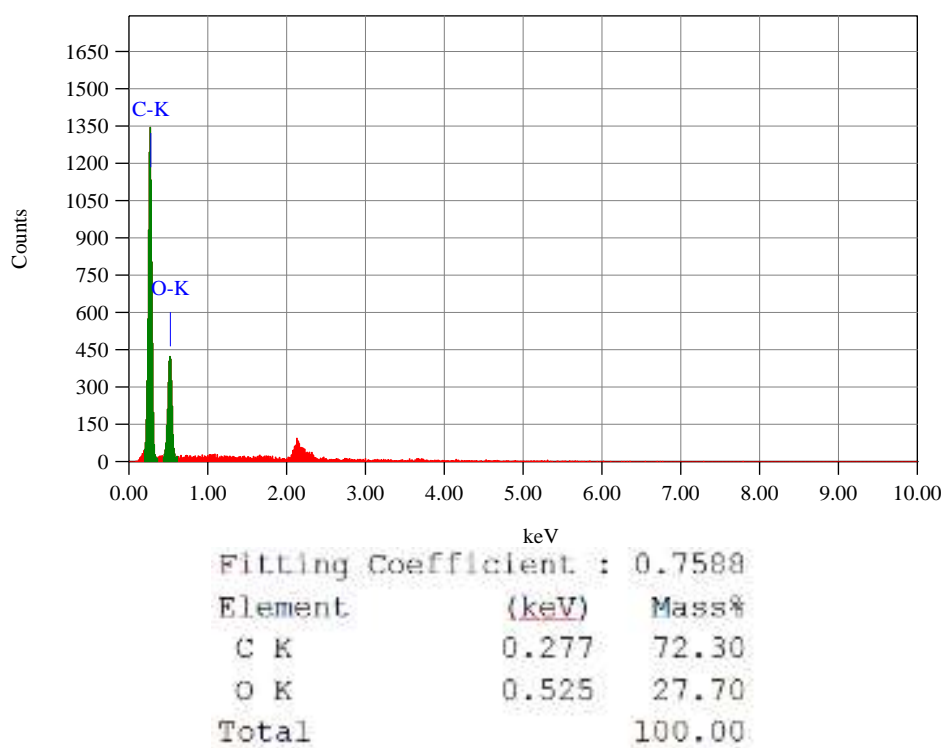

(b)

Figure 11. (a) SEM and (b) EDS spectra for paper in mineral oil aged at $120^{\circ} \mathrm{C}$ for 336 hours

SEM and EDS results of paper aged at 120 deg for 672 hours in mineral oil

Figure 12 (a) shows the SEM picture of a krafft paper aged at $120^{\circ} \mathrm{C}$ for a duration of 4 weeks (672 hours) taken using accelerated voltage of $10 \mathrm{kV}$ and magnification of $200 \mathrm{x}$. 


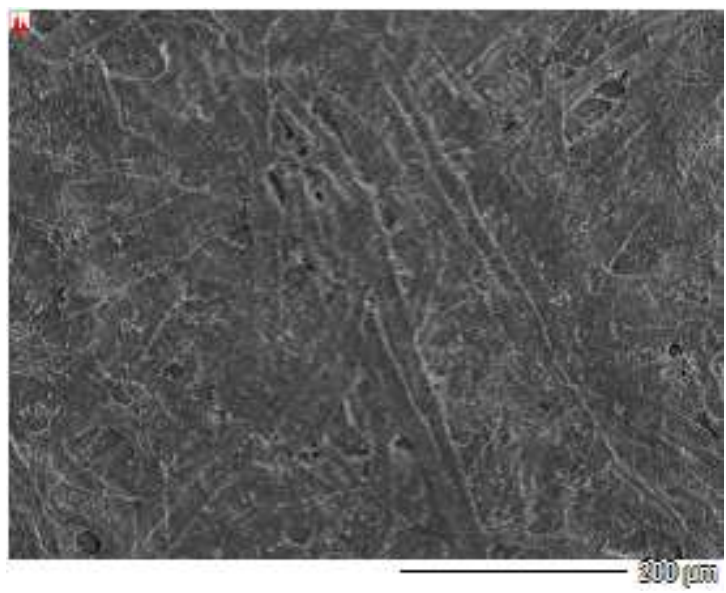

(a)

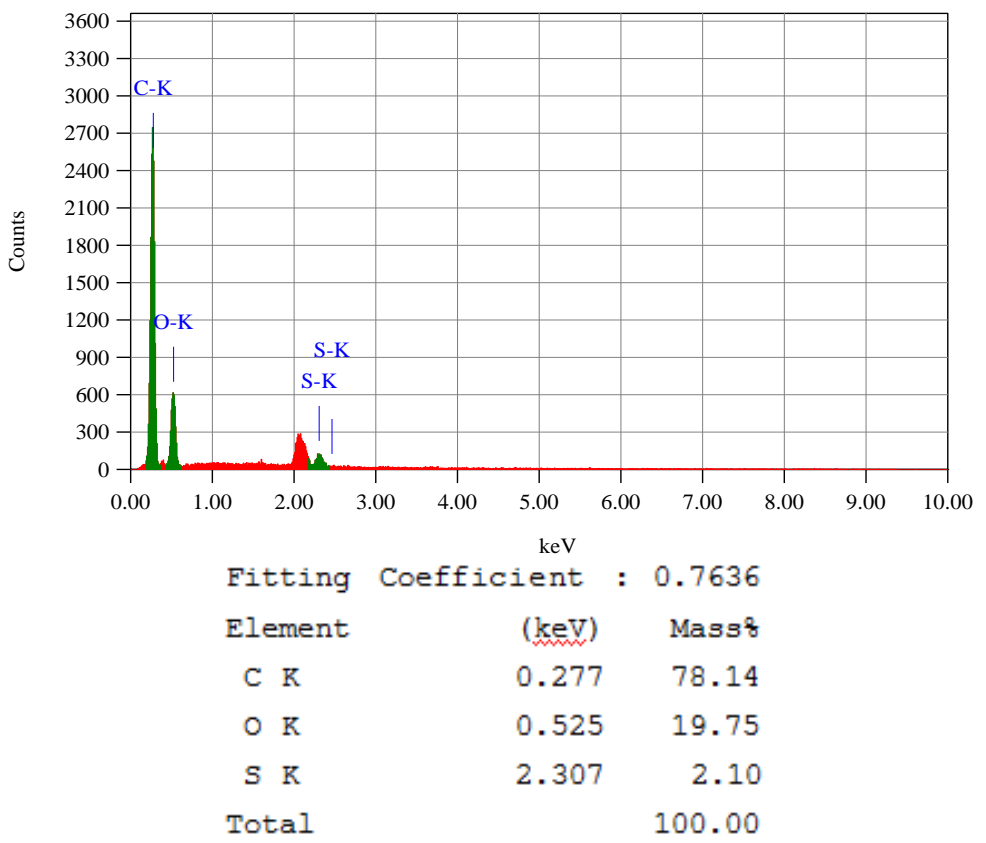

(b)

Figure 12. (a) SEM and (b) EDS spectra for paper in mineral oil aged at $120^{\circ} \mathrm{C}$ for 672 hours

It is seen that there are reasonable pore in the paper. Figure 12 (b) shows the EDS spectrum taken using JEOL 6510 at accelerated voltage of $10 \mathrm{kV}$ with energy range of $0-20 \mathrm{kV}$. From the spectrum it is seen that the aged paper consists of 3 elements, $\mathrm{C}, \mathrm{O}$ and $\mathrm{S}$ elements with mass percentage of $78.14 \%$ of $\mathrm{C}$ at energy of $0.277 \mathrm{kV}, \mathrm{O}$ of $19.75 \%$ observed at energy of $0.525 \mathrm{kV}$ and new element of S with mass percentage of $2.1 \%$ observed at energy of 2.307 $\mathrm{kV}$. It is clearly observed that C increased from $58.83 \%$ to $78.14 \%$. This is due to the migration from the oil into the paper and the reduction of oxygen in the paper because of reaction with oil in an thermal agitated oxidation and release CO gas as confirmed by DGA (dissolved gas analysis). As shown in the table 2, $110.3 \mathrm{ppm}$ CO gas was released under this aging condition. The appearance of new species $\mathrm{S}$ is due to the migration of $\mathrm{S}$ from the mineral oil. It is well known that mineral oils is made from a crude oil which contains plenty sulphur elements. During the refining process, most of these elements are removed, however, small 
amount of the sulphurs are still remaining. Sulphur is accepted to be the most corrosive element in transformer oil[26-30].

SEM and EDS results of paper aged at $150^{\circ} \mathrm{C}$ deg for 336 hours in mineral oil

Figure 13 (a) shows the SEM picture of a krafft paper aged at $150^{\circ} \mathrm{C}$ for a duration of 336 hours.

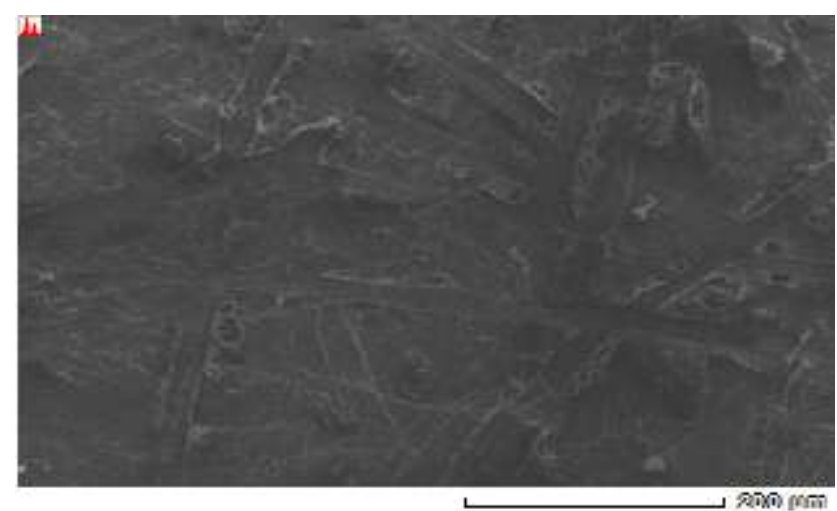

(a)

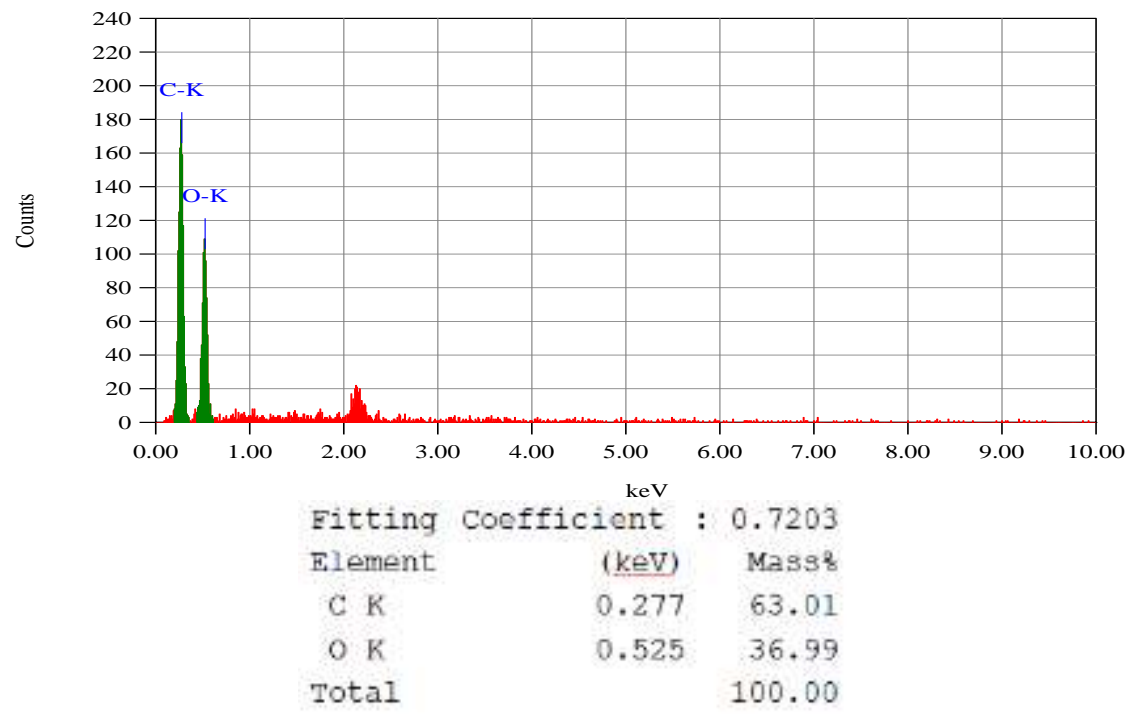

(b)

Figure 13. (a) SEM and (b) EDS spectra for paper in mineral oil aged at $150^{\circ} \mathrm{C}$ for 336 hours

Under aging temperature of $150 \mathrm{oC}$ up to 336 hours, the detected elements in the paper are $\mathrm{C}$ and $\mathrm{O}$ with composition of $63.01 \%$ of $\mathrm{C}$ which is detected at $0.277 \mathrm{keV}$ and $\mathrm{O}$ detected at $0.525 \mathrm{keV}$. However, they have different mass percentages. The data showed that mass percentage of $\mathrm{C}$ increased from $58.83 \%$ at initial condition to $63.01 \%$ after aging at $150^{\circ} \mathrm{C}$ for 336 hours. On the other hand oxygen reduced from $41.17 \%$ to $36.99 \%$. This is due to the migration from the oil into the paper and at the same time oxygen elements in the paper were consumed in an oxidation reaction with oil in a thermal agitated oxidation and release $\mathrm{CO}$ gas as confirmed by DGA (dissolved gas analysis). This process released $\mathrm{CO}$ gas with concentration of 94,10 as shown in the table 2 . No S element was detected at this stage. 
Suwarno, et al.

SEM and EDS results of paper aged at $150^{\circ} \mathrm{C}$ deg for 672 hours in mineral oil

Figure 14 (a) shows the SEM picture of a krafft paper aged at $150^{\circ} \mathrm{C}$ for a duration of 672 hours.

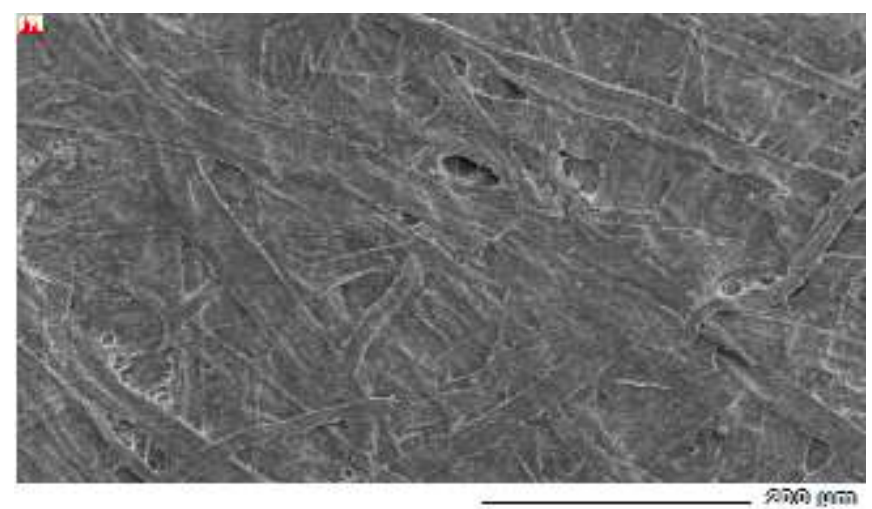

(a)

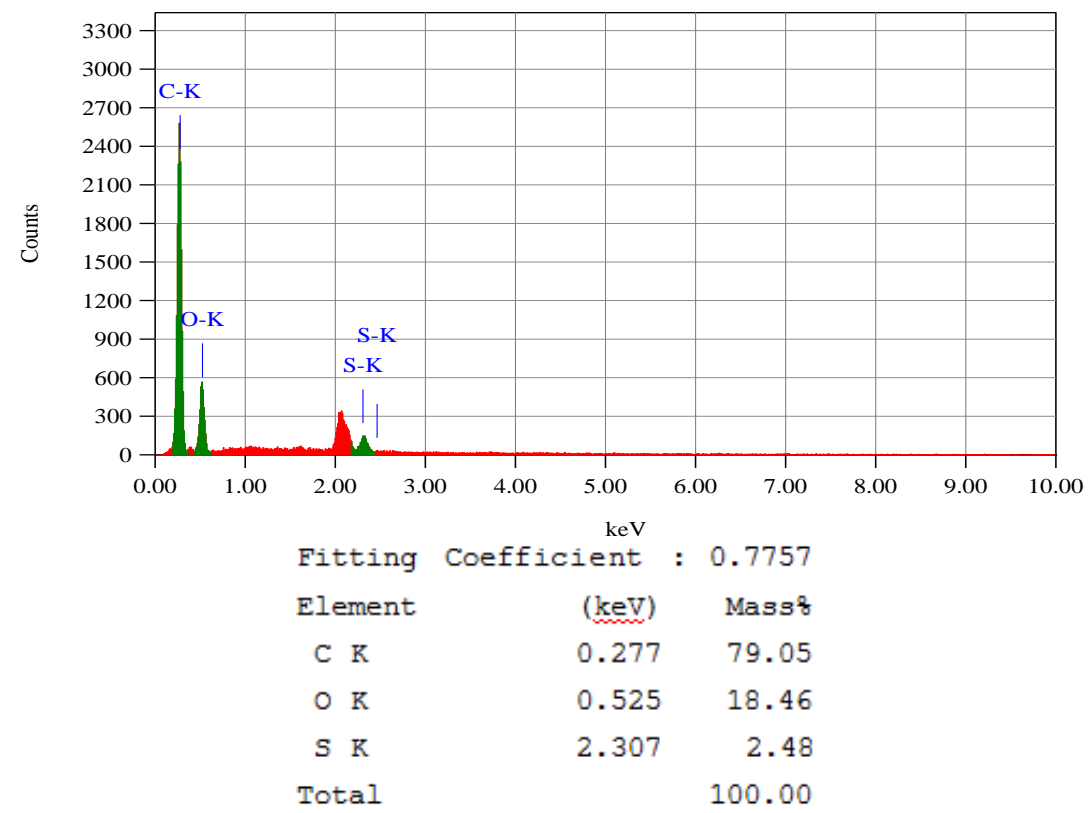

(b)

Figure 14. (a) SEM and (b) EDS spectra for paper in mineral oil aged at $150^{\circ} \mathrm{C}$ for 672 hours.

Figure 14(a) shows the SEM picture of a krafft paper aged at $150^{\circ} \mathrm{C}$ for a duration of 4 weeks (672 hours) taken using accelerated voltage of $10 \mathrm{kV}$ and magnification of $200 \mathrm{x}$. It is seen that pores are reasonably reduced due to oil migration into the paper pores and light degradation was already taken place. Figure 14 (b) shows the EDS spectrum taken using JEOL 6510 at accelerated voltage of $10 \mathrm{kV}$ with energy range of $0-20 \mathrm{keV}$. It is clearly seen from the spectrum that under this aging condition, 3 elements are observed. $\mathrm{C}$ was observed at energy of $0.277 \mathrm{keV}$ with mass percentage of 79.05 , while $\mathrm{O}$ at $0.525 \mathrm{keV}$ with percentage of 18.46 $\%$. New element namely S was detected at energy of $2.307 \mathrm{keV}$ with mass percentage of 2.48 . As it was described for other aging condition the increase of $\mathrm{C}$ and the decrease of $\mathrm{O}$ was due to the migration of $\mathrm{C}$ into paper and at the same time the reduction of $\mathrm{O}$ from the paper in a oxidation process to form $\mathrm{CO}$ gas. The released gas was confirmed using DGA measurement 
with concentration of $438,15 \mathrm{ppm}$. The comparison of elements in new and aged kraft paper samples is shown in table 4.

Table 4. Comparison of elements in new and aged kraft paper samples

\begin{tabular}{|c|c|c|c|c|c|c|}
\hline Element & $\begin{array}{c}\text { Energy } \\
(\mathrm{keV})\end{array}$ & $\begin{array}{c}\mathrm{New} \\
(\%)\end{array}$ & $\begin{array}{c}\text { Aged at } \\
120^{\circ} \mathrm{C} \text { for } \\
336 \mathrm{~h} \\
(\%)\end{array}$ & $\begin{array}{c}\text { Aged at } \\
120^{\circ} \mathrm{C} \text { for } \\
672 \mathrm{~h} \\
(\%)\end{array}$ & $\begin{array}{c}\text { Aged at } \\
150^{\circ} \mathrm{C} \text { for } \\
336 \mathrm{~h} \\
(\%)\end{array}$ & $\begin{array}{c}\text { Aged at } \\
150^{\circ} \mathrm{C} \text { for } \\
672 \mathrm{~h} \\
(\%)\end{array}$ \\
\hline $\mathrm{C}$ & 0.277 & 58.83 & 72.3 & 78.14 & 63.01 & 79.05 \\
\hline $\mathrm{O}$ & 0.525 & 41.17 & 27.7 & 19.75 & 36.99 & 18.46 \\
\hline $\mathrm{S}$ & 3.312 & & & 2.10 & & 2.48 \\
\hline
\end{tabular}

From the table it is seen that the thermal aging in ester-kraft paper composite insulation increased the $\mathrm{C}$ element due to oil permeation into the paper. However, the thermal aging reduced the $\mathrm{O}$ element of paper because of the usage of oxygen element from the paper in oxidation reaction to release $\mathrm{CO}$ which was confirmed by DGA. The small $\mathrm{S}$ element appeared after aging came from the mineral oil.

\section{Conclusion}

We have investigated the thermal aging on paper-mineral transformer oil composite insulation system at $120^{\circ} \mathrm{C}$ and $150^{\circ} \mathrm{C}$ with duration up to 672 hours. Dielectric properties of oil were investigated using IEEE and IEC standard. Gases generated during the aging were determined using DGA method. The morphological aging of the kraft paper was investigated using SEM (scanning electron microscopy) while chemical element change was investigated using EDS (energy dispersive spectroscopy) with accelerated voltage of $0.3-30 \mathrm{kV}$. The experimental results showed that the dielectric properties decreased with the increasing of duration and temperature of aging. Breakdown voltage increases after heating the samples. The phenomena was due to the reduction of water content which was from $64 \mathrm{ppm}$ to $43 \mathrm{ppm}$ after 336 hours. As the time elapsed the breakdown voltage reduced again due to the degradation of the oil as well as paper as indicated by the darker color of the aged oils. DGA date indicated that some hydrocarbon gases were detected in aged samples. They are $\mathrm{H}_{2}$ (Hydrogen), $\mathrm{CH}_{4}$ (Methane), $\mathrm{C}_{2} \mathrm{H}_{2}$ (Acetylene), $\mathrm{C}_{2} \mathrm{H}_{4}$ (ethylene), $\mathrm{C}_{2} \mathrm{H}_{6}$ (ethane), and $\mathrm{CO}$ (Carbon Monoxide). $\mathrm{H}_{2}$ and $\mathrm{C}_{2} \mathrm{H}_{2}$ gases are not generated in this experiment. $\mathrm{CO}$ gas was obtained as the result thermal aging of paper insulation through oxidation process. The increase of temperature and the longer the aging period will increase the concentration of CO. The EDS analysis showed that during aging the $\mathrm{C}$ element increased while $\mathrm{O}$ element decreased. EDS data of krafft paper aged at $120^{\circ} \mathrm{C}$ for a duration of 4 weeks (672 hours) taken using JEOL 6510 at accelerated voltage of $10 \mathrm{kV}$ with energy range of $0-20 \mathrm{keV}$ showed that the aged paper consists of 3 elements, $\mathrm{C}, \mathrm{O}$ and $\mathrm{K}$ elements with mass percentage of $75.23 \%$ of $\mathrm{C}$ at energy of $0.277 \mathrm{keV}$, $\mathrm{O}$ of $21.69 \%$ observed at energy of $0.525 \mathrm{keV}$ and new element of $\mathrm{K}$ with mass percentage of 3.08 observed at energy of $3.312 \mathrm{keV}$. It is clearly observed that $\mathrm{C}$ increased from $58.83 \%$ to $75.23 \%$. This is due to the migration from the ester into the paper on the other hand oxygen reduced from $41.17 \%$ to $21.69 \%$ because the oxygen from the paper reacted with oil in an oxidation and release $\mathrm{CO}$ gas as confirmed by DGA (dissolved gas analysis). Similar behavior was observed for aging at $150^{\circ} \mathrm{C}$. EDX date taken from sample aged at $120^{\circ} \mathrm{C}$ with duration of 672 hours showed that $\mathrm{C}, \mathrm{O}$ and $\mathrm{S}$ elements were detected with mass percentage of $78.14 \%$ of $\mathrm{C}$ at energy of $0.277 \mathrm{keV}, \mathrm{O}$ of $19.75 \%$ observed at energy of $0.525 \mathrm{keV}$ and $\mathrm{S}$ with mass percentage of $2.1 \%$ observed at energy of $2.307 \mathrm{keV}$. The increase of $\mathrm{C}$ element was due to the migration from the oil into the paper and the reduction of oxygen in the paper because of reaction with oil in an thermal agitated oxidation and release $\mathrm{CO}$ gas as confirmed by DGA (dissolved gas analysis). Similar behavior was detected for aging at $150^{\circ} \mathrm{C}$ and aging duration of 672 hour but with higher percentage of changes. 


\section{Acknowledgements}

This study was financially supported by RISTEK DIKTI 2016

\section{References}

[1]. A.M. Emsley; R.J. Heywood ; M. Ali ; X. Xiao, Degradation of cellulosic insulation in power transformers .4. Effects of ageing on the tensile strength of paper, IEE Proceedings - Science, Measurement and Technology (Volume: 147, Issue: 6, Nov 2000 ), Page(s): $285-290$

[2]. P.Verma, D.S.Chauhan and Preetinder Singh, Effects on Tensile Strength of Transformer Insulation Paper under Accelerated Thermal and Electrical Stress, Annual Report Conference on Electrical

[3]. Lifetime estimation of vegetable and mineral oil impregnated paper for power transformers Alexandra Ciuriuc; Laurentiu Marius Dumitran; Petru V. Noţingher; Laurenţiu Viorel Bădicu; Radu Setnescu; Tanta Setnescu2016 IEEE International Conference on Dielectrics (ICD)Year: 2016, Volume: 2 Pages: 720 - 723

[4]. Calculation of the remaining lifetime of power transformers paper insulationBogdan Gorgan; Petru V. Notingher; Jos M. Wetzer; Harry F. A. Verhaart; Peter A. A. F. Wouters; Arjan van Schijndel; Gabriel Tanasescu 2012 13th International Conference on Optimization of Electrical and Electronic Equipment (OPTIM)Year: 2012 Pages: 293 300

[5]. Lifetime estimation of vegetable and mineral oil impregnated paper for power transformers Alexandra Ciuriuc; Laurentiu Marius Dumitran; Petru V. Noţingher; Laurenţiu Viorel Bădicu; Radu Setnescu; Tanta Setnescu2016 IEEE International Conference on Dielectrics (ICD) Year: 2016, Volume: 2 Pages: 720 - 723,

[6]. W. Tillar Shugg, Handbook of Electrical and Electronic insulating Materials, IEEE Press, 1995.

[7]. Suwarno and J. Marbun, Effect of thermal aging on the dielectric properties of mixture between mineral oil and natural ester, TENCON 2015 - 2015 IEEE Region 10 Conference, Year: 2015

[8]. J. Jung-Il, A. Jung-Sik, and H. Chan-Su, "Accelerated aging effects of mineral and vegetable transformer oils on medium voltage power transformers, IEEE Transactions on Dielectrics and Electrical Insulation, vol. 19, 2012, pp. 156-161.

[9]. T. K. Saha and P. Purkait, "Understanding the impacts of moisture and thermal ageing on transformer's insulation by dielectric response and molecular weight measurements, IEEE Transactions on Dielectrics and Electrical insulation, vol. 15, Issue 2, 2008, pp. 568-582

[10]. Josue, F., Arifianto, I., Saers, R., Hilber, P., Suwarno, Transformer hot-spot temperature estimation for short-time dynamic loading,, Proceedings of IEEE International Conference on Condition Monitoring and Diagnosis, Bali, 23-27 September 2012 , pp. 217-220

[11]. Norazhar Abu Bakar; A. Abu-Siada; S. Islam, A review of dissolved gas analysis measurement and interpretation techniques, IEEE Electrical Insulation Magazine, Vol. 30, Issue 3, 2014, pp. 39-40

[12]. Ming-Ta Yang; Li-Siang $\mathrm{Hu}$, Intelligent fault types diagnostic system for dissolved gas analysis of oil-immersed power transformer, IEEE Transactions on Dielectrics and Electrical Insulation, Vol. 20, issue 6, 2013, pp. 2317-2324

[13]. Suwarno and F. Salim, "Effects of Electric Arc on The Dielectric Properties of Liquid Dielectrics," IEEE 8th International Conference on Properties \& applications of Dielectric Materials, bali 2006, pp. 482-485

[14]. G. Zadora, Z. Brozek-Mucha, SEM-EDX, A useful tool for Forensic examinations, Material, chemistry and Physics, Vol. 81, issue 2-3, 2003, pp. 345-348

[15]. M. Nusp, W. Wegscheider, J. Angeli, W. Posch, M. Mayr, Qualitative and quantitative determination of micro-inclusions by automated SEM/EDX analys, Analytical and Bioanalytical Chemistry, Vol. 379, Issue 4, 2004, pp 640-645 
[16]. F. Fay, I. Linossier, V. Langlois, D. Haras SEM and EDX analysis: Two powerful techniques for the study of antifouling paints, Progress in Organic Coatings, Vol. 54, Issue 3, 2005, Pages 216-223

[17]. P. McShane, K. J. Rapp, J. L. Corkran, G. A. Gauger and J. Luksich, Aging of Kraft paper in natural ester dielectric fluid, IEEE 14th Int'l. Conf on Dielectr. Liquids, Graz 2002, pp. 173-177

[18]. IEEE 1538-2000, IEEE Guide for Determination of maximum Winding Temperature Rise in Liquid-Filled Transformers

[19]. IEC, Insulating Liquids - Determination of The Breakdown Voltage at Power Frequency Test Method, IEC, Standard Report 60156, 2008

[20]. IEC, Insulating Liquids - Measurement of Relative Permittivity, Dielectric Dissipation Factor and D.C Resistivity, IEC, Standard Report 60247, 2004

[21]. IEEE Guide for the Interpretation of Gases Generated in Oil-Immersed Transformers, IEEE Standard No. C57.104-2008, 2009

[22]. Standard Test Method for Analysis of Gases Dissolved in Electrical Insulating Oil by Gas Chromatography, ASTM Standard, No D3612 - 02(2009)

[23]. Abu-Siada and S. Islam, "A new approach to identifY power transformer criticality and asset management decision based on dissolved gas-in-oil analysis, IEEE Transactions on Dielectrics and Electrical insulation, vol. 19, Isue 3, 2012, pp. 1007-1012.

[24]. Suwarno and Santosh, Effect of electric arc on dielectric characteristic and dissolved gases of mineral oil, Research Journal of Applied Sciences, Vol 6, issue 6, 2011, pp. 354360

[25]. Nenad Stojilovic, Why Can't We See Hydrogen in X-ray Photoelectron Spectroscopy? Journal of Chem. Education, Vol 89, No. 10, 2012, pp 1331-1332.

[26]. Akshatha A, Anjana.K, D. Ravindra, G. Vishwanath, J. Sundara Rajan, Study of Copper Corrosion in Transformers due to Sulphur in oil using Chemical Methods, CEIDP 2012, pp 395-398.

[27]. Jill R. Smith; P. K. Sen. Corrosive Sulfur in Transformer Oil, IEEE Industry Applications Society Annual Meeting, 2010, pp. 1-4

[28]. Jian Li , Zhiman He, Lianwei Bao and Lijun Yang, Influences of Corrosive Sulfur on Copper Wires and Oil-Paper Insulation in Transformers, Energies, Vol. 4, 2011, pp. $1563-1573$

[29]. R.A. Venkata Lakshmi, T.S.R. Murthy, Studies on effect of Copper corrosion passivators on the Paper insulated copper conductor by XRD, SEM and EDX analysis, International Journal of Engineering Research and Applications, Vol. 2, Issue 5, 2012, pp.1295-1299

[30]. Bramantyo, A.P., Suwarno, Serra, S., Cavallini, A., Montanari, G.C., Thermal ageing and corrosive sulphur effect on partial discharge and electrical conductivity of oil impregnated paper, Proceedings 2nd IEEE Conference on Power Engineering and Renewable Energy, Bali 9-11 December 2014, Pages 163-166 


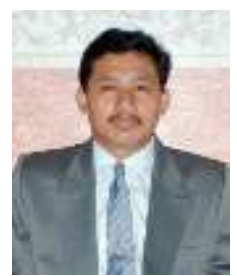

Suwarno received BSc and $\mathrm{MSc}$ from The Department of Electrical Engineering, Institut Teknologi Bandung, Bandung, Indonesia in 1988 and 1991 respectively and $\mathrm{PhD}$ from Nagoya University, Japan in 1996. His research interests are High Voltage Insulating Materials and Technology, Electromagnetic Compatibility and High Voltage Industrial Application. Dr. Suwarno is recipient of The Best Paper Award from IEEE Queensland (ICPADM 1994), Excellent Paper Awards from IEE Japan 1994 and 1995 and Best Paper Presentation from ACED (Seoul 2003). Dr. Suwarno is a member of International Advisory Committee of several International Conferences. He was The General Chairman of National Conference on High Voltage Engineering 1998, IEEE ICPADM 2006, ICEEI 2007 and IEEE CMD, Bali 2012. Dr Suwarno was The Vice Dean and Dean of The School of Electrical Engineering and Informatics, Institut Teknologi Bandung and currently, he is a Professor and the Head of Electrical Power Engineering Research Division of ITB. Dr. Suwarno can be reached at suwarno@ieee.org.

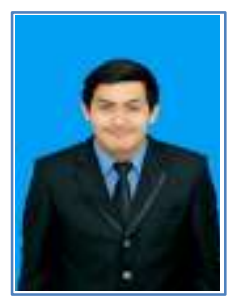

My name is Rizky Auglius Pasaribu. I was born in Medan on 12 October 1995. I study at Bandung Institute of Technology majoring in Electrical Power Engineering, with GPA 3.16 from 4.00. When studying, I was active also in the organization, including Himpunan Mahasiswa Elektroteknik-ITB and Unit Kesenian Sumatera Utara-ITB. In addition, in 2015 I had the opportunity to intern in PT Kaltim Prima Coal. 